\title{
THE CIRCULATION RATE IN RELATION TO METABOLISM IN THYROID AND PITUITARY STATES (DECHOLIN METHOD) ${ }^{i}$
}

\author{
By J. W. MACY,2 T. S. CLAIBORNE AND L. M. HURXTHAL \\ (From the Medical Department of the Lahey Clinic, Boston)
}

(Received for publication August 30, 1935)

The relationship between metabolism and the velocity of blood flow in thyroid disease has been studied by numerous investigators $(1,2,3,4,5$, $6,7)$, all of whom have demonstrated that the velocity of blood flow is increased in hyperthyroidism and decreased in myxedema. In addition, the circulation time or the velocity of blood flow was found to be increased in anemia and decreased in congestive heart failure, while in hypertension, no variation from the normal circulation rate was found.

One purpose of this study was to determine if there existed a change in circulation rate in conditions in which the metabolic rate was abnormal, but in which there appeared no evidence of abnormal thyroid function. It is well known that in acromegaly (hyperpituitarism) associated with chromophile pituitary adenomas and hypopituitarism associated with chromophobe tumors the metabolic rate is definitely influenced; in the former it is increased and in the latter decreased. This is now generally considered to be due to secondary changes in thyroid activity from hyperplasia or hypoplasia as the result of increased or decreased effect of the pituitary thyrotropic hormone. The clinical manifestations of myxedema are usually lacking in hypopituitary cases with low metabolism as well as in many instances of hypometabolism of unknown cause. It was our prediction, therefore, that in these cases normal values for circulation time would be found.

\section{METHOD}

Winternitz, Deutsch and Brüll (5) first used decholin intravenously in studying circulation time, and since then additional observations with the use of this method by Gargill (6) and also

\footnotetext{
1 Read by title at the meeting of the American Society for Clinical Investigation at Atlantic City in May, 1935.

2 This study was begun in cooperation with Dr. J. W. Macy, now deceased.
}

by Tarr, Oppenheimer and Sager (7) have shown it to be fairly accurate.

As suggested by Gargill (6) and by Tarr, Oppenheimer and Sager (7), we used 2 or $3 \mathrm{cc}$. of 20 per cent decholin intravenously, but in some cases $1 \mathrm{cc}$. gave a definite response. If too little decholin was used, the end point was not sharp, and the test was repeated. When the end point was definite, a repetition of the test invariably gave a rate checking closely with the first observation. The test was usually performed on the patient under basal conditions, but little difference was noted between the rate under basal conditions and when taken after the patient rested flat in bed for a period of 30 to 60 minutes. The injection was made rapidly, the time of injection varying from one to three seconds, two seconds being the usual time required. The velocity of blood flow in our studies was taken as the time from the end of the injection of decholin to the time when the bitter taste appeared in the patient's mouth. The end point was usually definite, the taste coming quickly. To compare our studies with others where the rate is measured from the start of the injection, one must add on the average, two seconds.

\section{REACTIONS}

The extent of unpleasant reactions noted by other observers using decholin has been nausea and at times vomiting, and in some cases there has been slight upper abdominal pain. We have had one death as the result of the injection of decholin and four unpleasant reactions. The death occurred in a middle aged woman with intractable asthma. Decholin was suggested to us and used in an attempt to alleviate the asthma. The patient was having asthmatic breathing before the injection was given. Two cubic centimeters of decholin were given rapidly intravenously and as no bitter taste was noted, the injection was continued slowly for its possible therapeutic effect. Scarcely more than 2 cc. had 
been given in addition when the patient was seized with a severe asthmatic state and died within three minutes despite the intravenous and intracardiac administration of adrenalin and the use of oxygen and artificial respiration. Two other reactions occurred in " allergic" patients. One patient with asthma was made worse by the injection of $15 \mathrm{cc}$. of decholin intravenously. Another patient who gave a history of hay fever previously had an attack of sneezing lasting eight minutes. until relieved by adrenalin. The attack came on within one minute after the use of $2 \mathrm{cc}$. of decholin intravenously. The two other reactions consisted of nausea and vomiting in patients without an allergic history. This type of reaction was rapid, and no residual effect was noted in the patient. In view of these experiences, we have made it a practice to avoid testing anyone with decholin in any case with a history of allergic manifestations.

\section{Normal individuals}

Fourteen normal individuals were tested (Table I). These patients were in the hospital for vari-

TABLE I

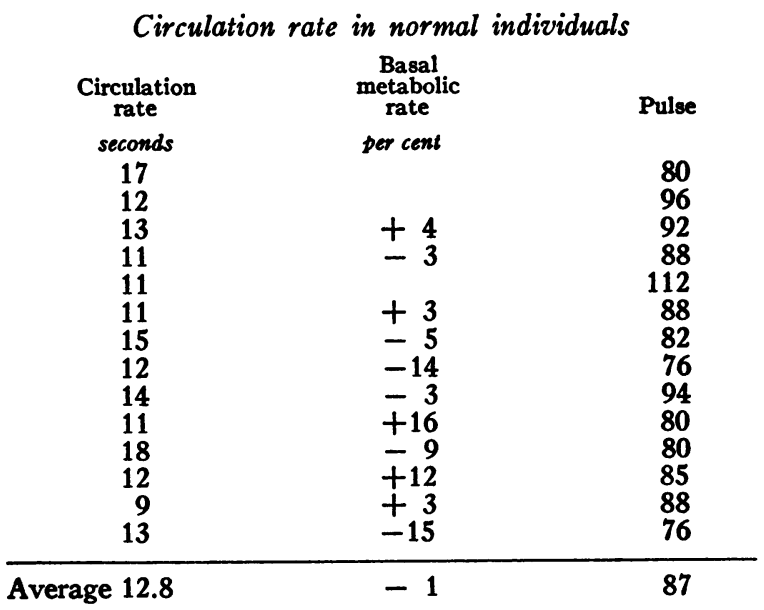

ous reasons. None of them, however, had any trouble which could seemingly alter the blood flow. The average circulation time in these patients was 12.8 seconds, not including injection time. The values obtained varied from 9 to 18 seconds. These results agree fairly well with those of Tarr et al., who reported an average of 13 seconds including injection time. Our results and those of Tarr et al. are more rapid than those reported by
Gargill who reports an average of 15 seconds in normal individuals not including injection time.

\section{Hypometabolism}

A group of 12 patients was studied having low metabolism and normal blood cholesterol without apparent myxedema (Table II). Most of these

TABLE II

Circulation rate in patients with low basal metabolic rate and no myxedema

\begin{tabular}{|c|c|c|c|}
\hline Circulation rate & $\begin{array}{l}\text { Basal meta- } \\
\text { bolic rate }\end{array}$ & Pulse & $\begin{array}{c}\text { Blood } \\
\text { cholesterol }\end{array}$ \\
\hline seconds & Der cent & & $\begin{array}{l}\text { mgm. per } \\
100 \text { cc. }\end{array}$ \\
\hline $\begin{array}{r}15 \\
14 \\
9 \\
12 \\
10 \\
12 \\
12 \\
10 \\
13 \\
14 \\
15 \\
13\end{array}$ & $\begin{array}{l}-17 \\
-20 \\
-18 \\
-17 \\
-34 \\
-21 \\
-38 \\
-24 \\
-34 \\
-21 \\
-30 \\
-30\end{array}$ & $\begin{array}{l}68 \\
56 \\
\\
68 \\
76 \\
64 \\
52 \\
84 \\
88 \\
64 \\
68 \\
62\end{array}$ & $\begin{array}{l}141 \\
263 \\
223 \\
227 \\
240 \\
168\end{array}$ \\
\hline Average 12.4 & -25 & 68 & 202 \\
\hline
\end{tabular}

patients had previously been operated upon for hyperthyroidism at a time from three months to two years before the test was made. The average circulation time in these cases was 12.4 seconds, with a variation of 9 to 15 seconds, which is in agreement with the rate in normal cases. It is evident in these cases that the low basal metabolism had no influence on the circulation as judged by the velocity of blood flow.

\section{Myxedema}

In contrast, we have observed the circulation time in $\mathbf{1 5}$ cases of myxedema and in 6 of these after treatment with desiccated thyroid (Tables III, IV, and V). The cases of myxedema are divided into those with obvious myxedema (Table III) and into those with questionable myxedema (Table IV). As further evidence of the patient's condition in relation to the thyroid function, blood cholesterol values are given as well as basal metabolism.

The average circulation rate in patients with obvious myxedema was 21.8 seconds with varia- 
TABLE III

Circulation rate in patients with obvious myxedema

\begin{tabular}{|c|c|c|c|}
\hline Circulation rate & $\begin{array}{c}\text { Basal meta- } \\
\text { bolic rate }\end{array}$ & Pulse & $\underset{\text { cholesterol }}{\text { Blood }}$ \\
\hline seconds & per cent & & $\begin{array}{l}\text { mgm. per } \\
100 \text { cc. }\end{array}$ \\
\hline $\begin{array}{l}19 \\
22 \\
20 \\
22 \\
25 \\
25 \\
17 \\
29 \\
17\end{array}$ & $\begin{array}{l}-26 \\
-25 \\
-27 \\
-5 \\
-39 \\
-24 \\
-18 \\
-31 \\
-26\end{array}$ & $\begin{array}{l}76 \\
56 \\
40 \\
60 \\
68 \\
52 \\
76 \\
60 \\
68\end{array}$ & $\begin{array}{l}410 \\
206 \\
422 \\
455 \\
420 \\
358 \\
446 \\
384 \\
312\end{array}$ \\
\hline Average 21.8 & -25 & 62 & 379 \\
\hline
\end{tabular}

TABLE IV

Circulation rate in patients with questionable myxedema

\begin{tabular}{|c|c|c|c|}
\hline Circulation rate & $\begin{array}{l}\text { Basal meta- } \\
\text { bolic rate }\end{array}$ & Pulse & $\begin{array}{c}\text { Blood } \\
\text { cholesterol }\end{array}$ \\
\hline seconds & per cent & & mgm. per \\
\hline $\begin{array}{l}21 \\
27 \\
14 \\
15 \\
12 \\
21\end{array}$ & $\begin{array}{l}-1 \\
-30 \\
-18 \\
-16 \\
-33 \\
-27\end{array}$ & $\begin{array}{l}68 \\
44 \\
60 \\
76 \\
80 \\
48\end{array}$ & $\begin{array}{l}256 \\
161 \\
345 \\
162 \\
458 \\
555\end{array}$ \\
\hline Average 18.3 & -21 & 63 & 323 \\
\hline
\end{tabular}

TABLE $v$

Circulation rates in patients with myxedema

\begin{tabular}{|c|c|c|c|c|c|}
\hline \multicolumn{3}{|c|}{ Before treatment } & \multicolumn{3}{|c|}{ After treatment } \\
\hline Circulation rate & $\begin{array}{c}\text { Blood } \\
\text { choles- } \\
\text { terol }\end{array}$ & $\begin{array}{c}\text { Basal } \\
\text { metab- } \\
\text { olism }\end{array}$ & $\begin{array}{l}\text { Circula- } \\
\text { tion } \\
\text { rate }\end{array}$ & $\begin{array}{c}\text { Blood } \\
\text { choles- } \\
\text { terol }\end{array}$ & $\begin{array}{c}\text { Basal } \\
\text { metab- } \\
\text { olism }\end{array}$ \\
\hline seconds & $\begin{array}{c}\underset{p g m}{\operatorname{mgm}} \\
100 \mathrm{cc} .\end{array}$ & per cent & seconds & $\begin{array}{c}\text { mgm. } \\
\text { per } \\
100 \text { cc. }\end{array}$ & per cent \\
\hline $\begin{array}{l}19 \\
20 \\
21 \\
25 \\
17 \\
17\end{array}$ & $\begin{array}{l}410 \\
422 \\
256 \\
420 \\
446 \\
312\end{array}$ & $\begin{array}{l}-26 \\
-27 \\
-1 \\
-39 \\
-18 \\
-26\end{array}$ & $\begin{array}{l}13 \\
13 \\
10 \\
12 \\
11 \\
11\end{array}$ & $\begin{array}{l}216 \\
182 \\
223 \\
220 \\
158 \\
221\end{array}$ & $\begin{array}{l}-2 \\
-9 \\
-11 \\
-29 \\
+31 \\
+25\end{array}$ \\
\hline Average 19.8 & 378 & -23 & 11.7 & 203 & +1 \\
\hline
\end{tabular}

tions from 17 to 29 seconds. The metabolism in these cases varied from -5 to -29 and the blood cholesterol from 206 to 455 . In the borderline cases the average rate was 18.3 seconds with variations from 12 to 27 seconds. With the restoration of the metabolism and blood choles- terol to normal levels after thyroid administration, the circulation quickened.

TABLE VI

\begin{tabular}{|c|c|c|}
\hline $\begin{array}{l}\text { Circulation } \\
\text { rate } \\
\text { seconds }\end{array}$ & $\underset{\text { metabolism }}{\text { Ber cent }}$ & 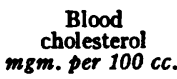 \\
\hline $\begin{array}{l}10 \\
13 \\
13 \\
12 \\
23\end{array}$ & $\begin{array}{l}-30 \\
-31 \\
-15 \\
-20 \\
-25\end{array}$ & $\begin{array}{l}219 \\
195 \\
200 \\
234 \\
200\end{array}$ \\
\hline
\end{tabular}

\section{Hypopituitarism}

Five typical cases of verified pituitary chromophobe adenoma were studied (Table VI). In Case 1, six months after operation on the pituitary, the metabolism was normal and the circulation rate was the same. This suggests that the patient regained normal pituitary function as indicated by the return of the basal metabolic rate to normal, and that there had been no change in the thyroid state as indicated by the circulation time.

As stated previously in this paper, normal circulation rates were anticipated in these, because there is no obvious circulatory change in the hypometabolism cases, which are not primarily of thyroid origin. Although we have not had the opportunity to study a case with active acromegaly, we should anticipate in view of the above findings, no actual increase in circulation rate with the elevated metabolic rate, such as occurs in pure hyperthyroidism. Since we realize the inadequacy of the small number of cases observed further observations are needed to confirm these views.

The duration of hypopituitarism and its effect on the thyroid might be considered to influence the end result, and a picture more akin to myxedema arise, yet it is probable that hypopituitarism existed more than three years in one of our cases since partial blindness had been present during that time.

\section{CONCLUSIONS}

1. Circulation rate as measured by the decholin method gives satisfactory results.

2. The circulation rate is decreased in myxedema and normal in hypometabolism without myxedema.

3. Suggestive evidence is presented to show that the circulation rate is not affected in hypo- 
pituitary states in which the metabolism is abnormally low.

4. Several reactions and one death are reported following the use of decholin in determining circulation rates.

\section{BIBLIOGRAPHY}

1. Weiss, S., Robb, G. P., and Blumgart, H. L., The velocity of blood flow in health and disease as measured by the effect of histamine on the minute vessels. Am. Heart J., 1928-29, 4, 664.

2. Robb, G. P., and Weiss, S., A method for the measurement of the velocity of the pulmonary and peripheral venous blood flow in man. Am. Heart J., 1933, 8, 650.
3. Blumgart, H. L., and Yens, O. C., Studies on the velocity of blood flow. I. The method utilized. J. Clin. Invest., 1927, 4, 1.

4. Blumgart, H. L., The velocity of blood flow in health and disease. Medicine, 1931, 10, 1.

5. Winternitz, M., Deutsch, J., and Brüll, Z., Eine klinisch brauchbare Bestimmungsmethode der Blutumlaufszeit mittels Decholininjektion. Med. Klin., 1931, 27, 986.

6. Gargill, S. L., The use of sodium dehydrocholate as a clinical test of the velocity of blood flow. New England J. Med., 1933, 209, 1089.

7. Tarr, L., Oppenheimer, B. S., and Sager, R. V., The circulation time in various clinical conditions determined by the use of sodium dehydrocholate. Am. Heart J., 1933, 8, 766. 